\title{
Post-stroke aphasia in famous writers: when Neurology left geniuses speechless
}

\author{
Afasia pós-AVC em escritores famosos: quando a Neurologia deixou gênios sem palavras \\ Bruno Kusznir VITTURI', Rubens José GAGLIARDI'
}

\begin{abstract}
Aphasia is a frequent and devastating stroke complication that does not spare even great writers. In these cases, not only one of the highest cognitive functions is suddenly lost but also the act of bringing beauty into the world. Herein, we discuss the case of three writers who had to abandon their art compulsorily due to a cerebrovascular disease: Charles Baudelaire, Ralph Waldo Emerson, and Stendhal. They were magnificent writers, united by excellence in literature and an inevitable destiny that restricted their art to just a few words. They are also examples of the proximity of Neurology to Art, History, and Literature.
\end{abstract}

Keywords: Neurology; Stroke; Aphasia; Art.

\section{RESUMO}

A afasia é uma complicação frequente e devastadora do acidente vascular cerebral (AVC), que não poupa nem mesmo os grandes escritores. Nesses casos, de repente, perde-se não apenas uma das funções cognitivas mais importantes, mas o ato de colocar a beleza no mundo. Discutimos o caso de três escritores que precisaram abandonar sua arte compulsoriamente devido a uma doença cerebrovascular: Charles Baudelaire, Ralph Waldo Emerson e Stendhal. Todos eles foram escritores magníficos, unidos pela excelência em literatura e por um destino inevitável que restringia sua arte a apenas algumas palavras. Eles também são exemplos da proximidade da Neurologia com a Arte, a História e a Literatura.

Palavras-chave: Neurologia; Acidente Vascular Cerebral; Afasia; Arte.

\section{INTRODUCTION}

Aphasia is a frequent and devastating stroke complication $^{1}$. Many famous writers have not escaped this condition ${ }^{2,3,4}$. In these cases, not only one of the highest cognitive functions is suddenly lost but also the act of bringing beauty into the world. Herein, we discuss the case of three magnificent writers who had to abandon their art compulsorily due to stroke.

\section{CHARLES BAUDELAIRE (1821-1867)}

Charles Baudelaire (Figure 1) is one of the most prominent French writers. He is best known for the controversial volume of poems "Les Fleurs du Mal'. In 1866, Baudelaire had a stroke that left him aphasic and hemiplegic before the age of $50^{5,6}$.
The stroke completely devastated Baudelaire. PouletMalassis once wrote: "Yesterday the paralysis was visible on the right side and the softening of the brain is obvious... There is, so to speak, no hope to save our friend. I just left him, he barely recognized me." He also described very well the seriousness of post-stroke aphasia: "The gravity of his disease, it seems to me, appears to be entirely in his inability to express himself. And it is clear that he is aware of this inability; but still, he acts like a quasi-mute, who would articulate one single word and try to make himself understood by varying intonations." The neurologist Charles Lasègue stated about Baudelaire's condition: "With an aphasia that serious, it is impossible to quantify feelings and intelligence, as expression is lacking even for the simplest ideas [...]”.

\footnotetext{
1Santa Casa de São Paulo, Faculdade de Ciências Médicas, Departamento de Neurologia, São Paulo SP, Brazil.

Bruno Kusznir VITTURI (D) https://orcid.org/0000-0002-2821-9042; Rubens José GAGLIARDI (D) https://orcid.org/0000-0002-3497-0174

Correspondence: Bruno Kusznir Vitturi; E-mail:z_azul@hotmail.com

Conflict of interest: There is no conflict of interest to declare.

Authors' contributions: BKV: manuscript design, data collection, conceptualization, writing. RJG: manuscript supervision, inspiration, coordination, critical review.

Received on June 22, 2020; Accepted on July 26, 2020.
} 
Baudelaire became frustrated with his aphasia for many reasons ${ }^{5,6}$. His neurological condition even aroused suicidal thoughts. He had a brilliant mind and knew he was unable to express himself. Ironically, Baudelaire was also extremely strict with the whole process of producing a book, to such an extent that, for instance, he took a room near the press to help supervise the book production. Besides, the man capable of awakening such beautiful and diverse feelings with his words found himself confined to incoherent monosyllables: "Cré nom!' an abbreviation of the expression, "Sacré nom de Dieu! ${ }^{6,7}$.

After surviving 18 months with global aphasia, he died without being able to work again and having to express his whole gamut of feelings and thoughts with two words. The poet who advised "always be a poet, even in prose" losthis words due to a stroke.

\section{RALPH WALDO EMERSON (1803-1882)}

Ralph Waldo Emerson (Figure 2) was an American poet, essayist, and lecturer, well known for leading the transcendentalist movement of the mid- $19^{\text {th }}$ century. He disseminated his thoughts through dozens of published essays and more than 1,500 public lectures across the United States ${ }^{8}$. Paradoxically, later in life, he had a stroke that would leave him aphasic for the rest of his life?

When he was 64 years old, his health started declining, and he began experiencing memory problems. He noticed that he had trouble organizing his thoughts and writing his lectures. He was suffering from non-fluent aphasia, probably Broca's aphasia, caused by a stroke ${ }^{10,11}$. From that moment on, his life would not be the same. His aphasia "distressed him

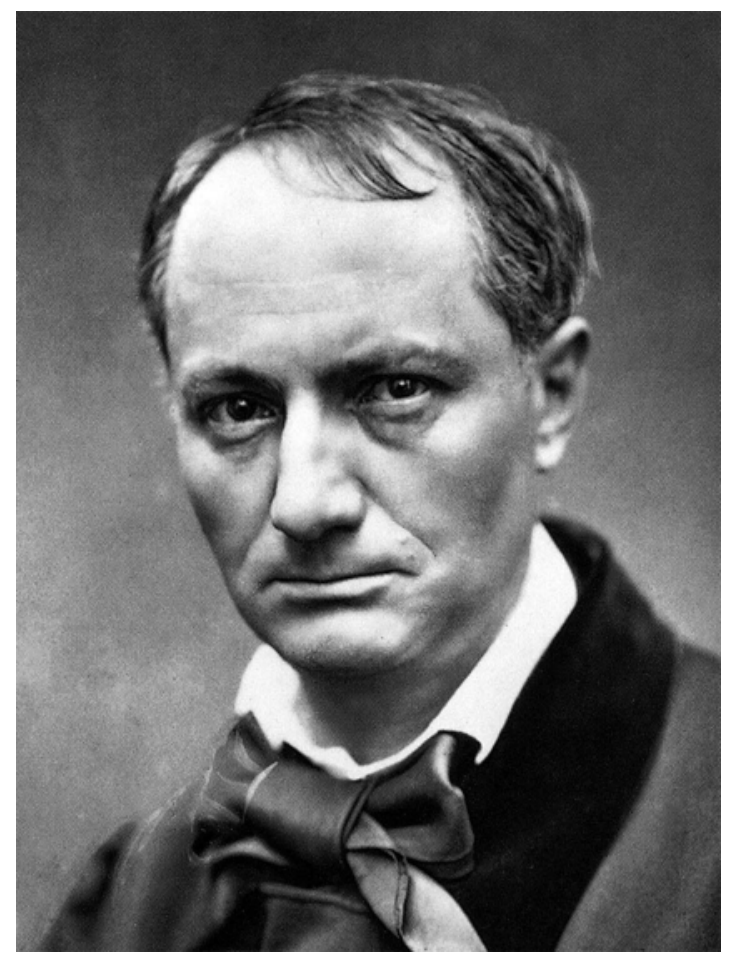

Figure 1. Charles Baudelaire, author of Les Fleurs du mal. personally and alarmed his family" Oliver Wendell Holmes wrote: "Emerson is afraid to trust himself in society much, on account of the failure of his memory and the great difficulty he finds in getting the words he wants. It is painful to witness his embarrassment at times".

The author of Nature did not stop trying to write essays and poetry for several years after the start of his aphasia. Indeed, Robert Richardson stated that Emerson continued to be able to read somewhat until the end of his life. He depended heavily on circumlocutions, speaking around the missing words by providing all related ones. The writer Ronald Bosco writes that "he rudely refused [his daughter] Ellen's assistance in the organization of his lectures and public readings, locked himself away in his study for long periods but emerged with little or nothing to show for the time he had spent there, and until May 1872, when Ellen insisted that he cease accepting them, routinely overextended himself by accepting invitations to lecture near and far" ${ }^{8,10}$. When people asked him how he felt, he answered, "Quite well; I have lost my mental faculties, but am perfectly well." As he neared the end of his life, he forgot his name at times, and communication became an increasing challenge. The author of Nature died in Massachusetts in 1882.

\section{STENDHAL (1783-1842)}

Stendhal (Figure 3), pseudonym of Marie-Henri Beyle, was one of the most original and complex French writers

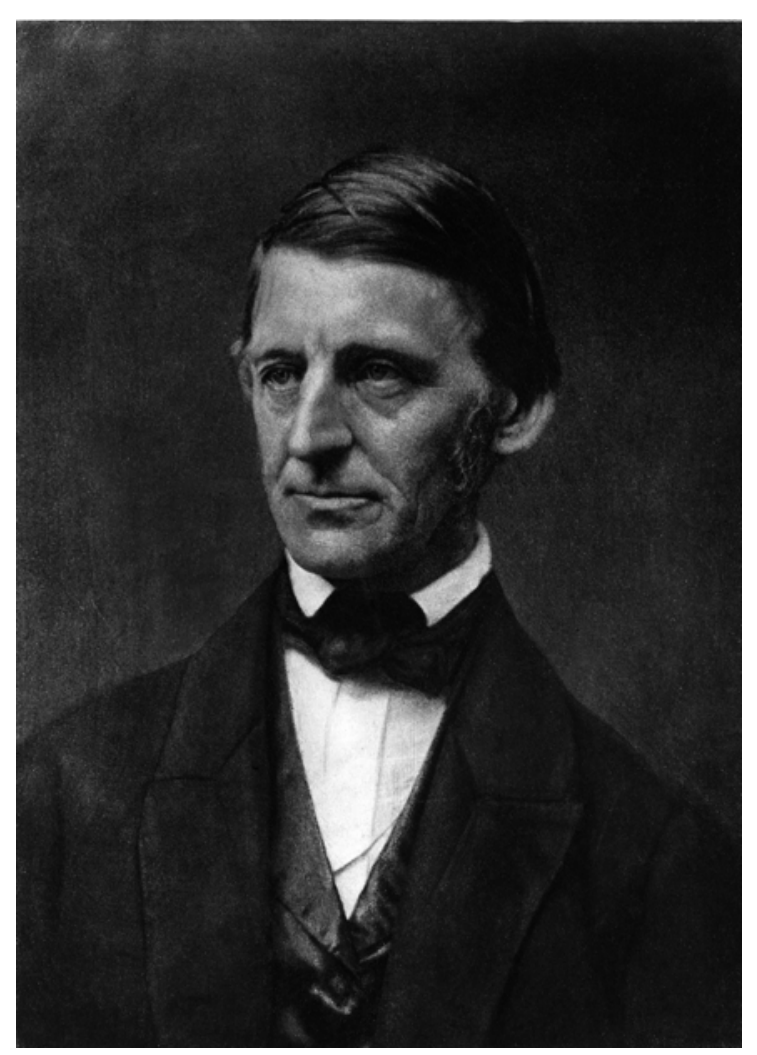

Figure 2. Ralph Waldo Emerson, an American Transcendentalist poet. 
of the $19^{\text {th }}$ century, chiefly known for his works of fiction ${ }^{12}$. Stendhal was born in Grenoble in 1783 and died of a stroke that was preceded several months before by transient ischemic attacks (TIAs), manifested as impaired speech. He had several spells of speech loss which he described very precisely in letters and notes. He wrote to his friend Domenico Fiore: "[...] then, four spells of the following sickness: All of a

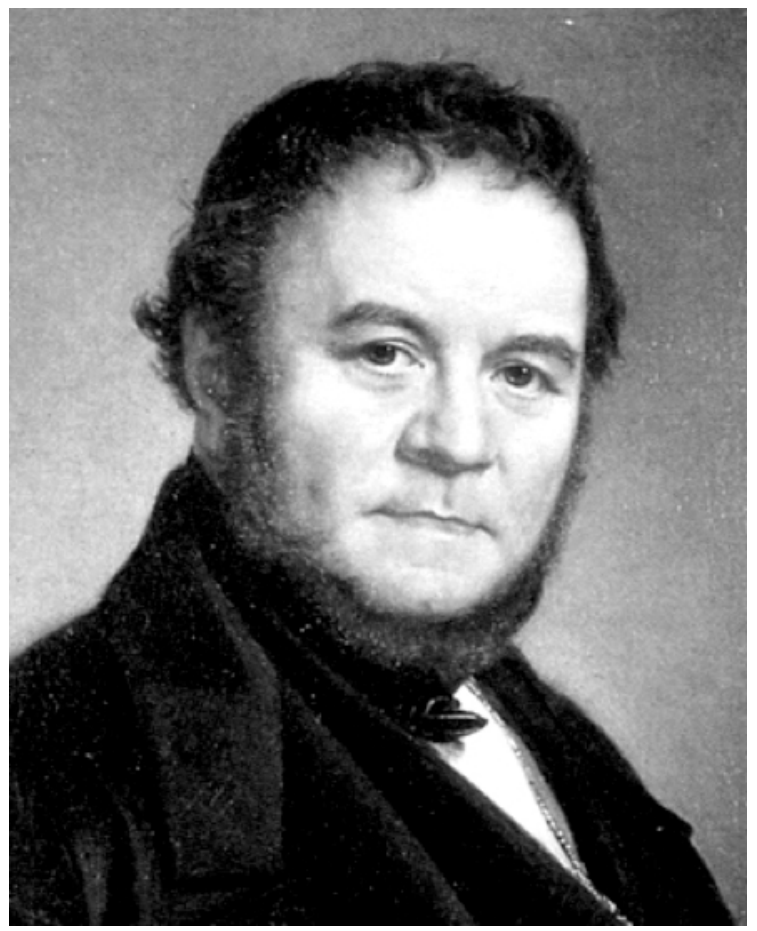

Figure 3. Stendhal, author of Le Rouge et le Noir. sudden I forget all French words. I can no longer say: 'Give me a glass of water.' I watch myself with curiosity; apart from the ability to use words, I keep all the natural properties of 'the animal'. It lasts eight to ten minutes; then, slowly, the memory of words comes back, and I am tired [...] I had four suppressions of any memory of all French language; it lasts six to eight minutes; ideas are fine, but without words. Ten days ago, while dining at the cabaret with Constantin, I made incredible efforts to find the word "glass"'13. The author also shared the strain caused by aphasia: "I am tired from having tried to write these three pages not too badly" and "I tried to speak, to train myself as it were, and to test whether I could say something in a connected order; but much as I forced my attention and my thoughts and proceeded with the utmost slowness, I became aware very soon of monstrous shapeless words that were absolutely different from those I intended; my immortal soul was at present as little master of the inner tools of language as it has been before of my writing"13.

On March 22, 1842, while walking down the street, the author of the eternal Le Rouge et le Noir suffered a lethal stroke $^{14}$. Interestingly, more than a sad case, Stendhal's TIAs a few months before his fatal stroke represented the first historical report of the warning nature of TIAs, which would be emphasized only over 100 years later ${ }^{11}$.

Irony. Frustration. Anguish. Affliction. Torture. Death. There are no words to describe what these three authors experienced. They illustrate how the unique ability to express, scrutinize, and refine thoughts and emotions under a pen can be vulnerable to cerebrovascular diseases. It would not be irrational to state that post-stroke aphasia, in these cases, precipitated the death of great geniuses.

\section{References}

1. Mattioli F. The clinical management and rehabilitation of post stroke aphasia in Italy: evidences from the literature and clinical experience. Neurol Sci. 2019 Mar; 40(7):1329-34. https://doi. org/10.1007/s10072-019-03844-0

2. VITTURI BK, SANVITO WL. The neurology behind three wounded French artists during the great world war. Arq Neuropsiquiatr. 2020 Feb; S0004-282X2020005002103. https://doi.org/10.1590/0004$282 \times 20190157$

3. Vitturi BK, Sanvito WL. What do flaubert, dostoevsky and machado de assis have in common with neurology? Arq Neuro-Psiquiatr. 2017 Dec;75(12):892-4. https://doi.org/10.1590/0004-282×20170145

4. Vitturi BK, Sanvito WL. Maurice Ravel's dementia: the silence of a genius. Arq Neuropsiquiatr. 2019 Feb;77(2):136-8. https://doi. org/10.1590/0004-282X20180134

5. Lebrun Y, Hasquin-Deleval J, Brihaye J, Flament J. [Charles Baudelaire's aphasia]. Rev Neurol (Paris). 1971 Oct;125(4):310-6. PMID: 4949431.

6. Dieguez S, Bogousslavsky J. Baudelaire's aphasia: from poetry to cursing. Front Neurol Neurosci. 2007;22:121-49. https://doi. org/10.1159/000102876

7. Teive HAG, Munhoz RP, Caramelli P. Historical aphasia cases: “Tan-tan”, "Vot-vot”, and “Cré nom!". Arq Neuro-Psiquiatr.
2011 Jun;69(3):555-8. https://doi.org/10.1590/s0004$282 \times 2011000400027$

8. Emerson RW. Collected Works of Ralph Waldo Emerson, Volume VIII: Letters and Social Aims. Cambridge (MA): Harvard University Press; 2010. ISBN 9780674035607.

9. Shenk D. The forgetting. Alzheimer's: Portrait of an Epidemic. New York (NY): Anchor; 2003. ISBN 9780385498388.

10. Moser B, Jr. RDR. Emerson: The Mind on Fire. Oakland (CA): University of California Press; 1996. ISBN: 9780520206892.

11. Emerson RW. The Selected Writings of Ralph Waldo Emerson. Nova York (NY): Random House; 1992

12. Palacios-Sánchez L, Botero-Meneses JS, Pachón RP, Hernández LBP, Triana-Melo JDP, Ramírez-Rodríguez S. Stendhal syndrome: A clinical and historical overview. Arq Neuro-Psiquiatr. 2018;76(2):120-3. https://doi.org/10.1590/0004-282×20170189

13. Bogousslavsky J, Assal G. Stendhal's aphasic spells: The first report of transient ischemic attacks followed by stroke. Front Neurol Neurosci. 2010;27:130-42. https://doi.org/10.1159/000311197

14. Teive HAG, Munhoz RP, Cardoso F. Proust, neurology and stendhal's syndrome. Eur Neurol. 2014;71(5-6):296-8. https://doi. org/10.1159/000357562 